\title{
Pulmonary Host Defenses and Oropharyngeal Pathogens
}

Galen B. Toews, M.D. Ann Arbor, Michigan Eric J. Hansen, Ph.D. Dallas, Texas Robert M. Strieter, M.D.

The lower respiratory tract is repetitively inoculated with oropharyngeal bacteria and yet pneumonia is an infrequent event. Efficient mechanisms of antibacterial defense are present in the respiratory tract that eliminate microbes before their presence or multiplication leads to disease in the majority of instances. Resident pulmonary defenses consist of aerodynamic defenses, the mucociliary apparatus, alveolar macrophages, complement, and surfactant. These resident defenses can be augmented by the development of an inflammatory response or the development of specific immunity. Significant species variability exists in the efficiency and mechanisms of clearance for oropharyngeal organisms. Streptococci are cleared promptly, Branhamella catarrhalis is cleared slowly, whereas non-typable Haemophilus influenzae multiply before being cleared. A dual phagocytic system of alveolar macrophages and recruited polymorphonuclear leukocytes is required for clearance of most oropharyngeal microbes. Systemic immunization can significantly enhance clearance of non-typable $\boldsymbol{H}$. influenzae, suggesting immunoprophylaxis might be possible for this organism.

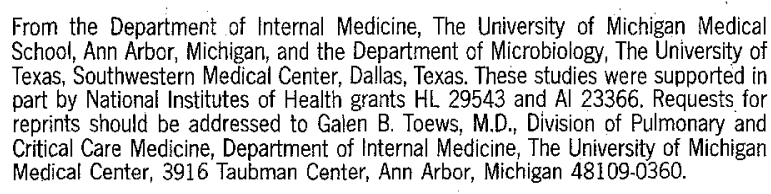

From the Department of Internal Medicine, The University of Michigan Medical School, Ann Arbor, Michigan, and the Department of Microbiology, The University of Texas, Southwestern Medical Center, Dallas, Texas. These studies were supported in part by National Institutes of Health grants HL 29543 and Al 23366. Requests for reprints should be addressed to Galen B. Toews, M.D., Division of Pulmonary and Critical Care Medicine, Department of Internal Medicine, The University of Michigan Medical Center, 3916 Taubman Center, Ann Arbor, Michigan 48109-0360.

$\mathbf{T}$ he largest epithelial surface exposed to the environment is the lung. Although the lung is continuously exposed to inspired air that contains microbes, early bacteriologic studies of bronchoscopically obtained tracheobronchial secretions and of lung biopsy material cultured at the time of thoracotomy suggested that the lung was a sterile organ [1-3]. This traditional concept of a continuously sterile lung has been challenged by more recent observations. Post mortem cultures of lung tissues obtained from previously healthy persons who died suddenly yielded small numbers of bacteria similar to those cultured from the pharynx [4]. Similarly, microbiologic studies of normal dogs showed that 89 percent of the lungs contained oropharyngeal organisms despite a study design that prevented agonal aspiration of upper respiratory tract secretions [5]. Finally, it has been demonstrated that pharyngeal contents enter the lower respiratory tract of normal persons during sleep. Pharyngeal secretions were noted in the lungs of 45 percent of normal persons and 70 percent of patients with altered consciousness. All normal subjects who slept soundly throughout the night aspirated oropharyngeal secretions. The foci of localized deposits of pharyngeal contents detected in human lungs and the foci of bacteria isolated from normal dog lungs were distributed in both gravity-and non-gravity-dependent areas $[5,6]$ which suggests that both aspiration and aerosolization of pharyngeal secretions are responsible for the deposition of bacteria from the oropharynx into the lung.

The number of bacteria inoculated into the lungs of normal persons is unknown. Two possibilities could account for the small number of bacteria isolated from normal lungs. A small number of bacteria might be deposited in the lung during sleep but cleared slowly, or many organisms might be deposited but cleared rapidly. The high density of bacteria in pharyngeal secretions suggests the latter [7,9]. Small volumes of oropharyngeal material can provide a significant inoculum of bacteria. Oropharyngeal bacteria are present in upper respiratory tract secretions in concentrations of $10^{7}$ bacteria/ml; therefore, aspiration of only $0.01 \mathrm{ml}$ would inoculate $10^{5}$ bacteria into the lower respiratory tract. These data suggest the existence of efficient mechanisms of defensc that are capable of climinating micro-organisms before their multiplication leads to disease.

The components of the pulmonary host defenses are distributed throughout the respiratory tract. Aerodynamic filtration and impaction occur in the nose, which removes large particulates, and cough and neurologic reflexes are important in the prevention of aspiration. In the lower respiratory tract, defenses include the mucociliary apparatus, alveolar macrophages, complement, and surfactant. All of these defenses are present at all time in normal persons and comprise the res- 
Figure 1. Determinants of bacterial clearance. The fraction of bacteria remaining in the lung are shown at various time points. The heavy black line depicts net bacterial clearanice, which is the variable measured in most clearance experiments. A small portion of the total decrease is due to physical removal by the mucociliary apparatus. The lower line represents the combiried effects of mucociliary clearance and in situ hilling in the absence of bacterial multiplication. Reprinted with permission from [49].

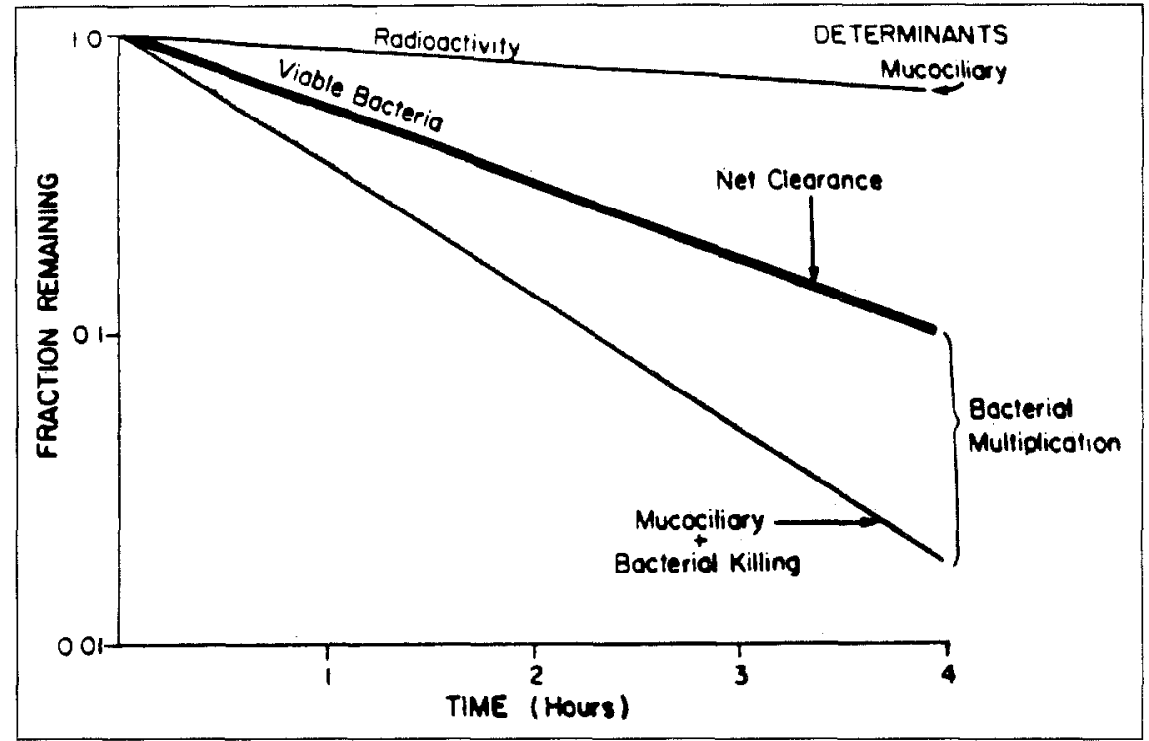

ident defenses of the lungs. These resident defenses deal with day-to-day challenges and effectively clear small inocula of bacteria. However, the combination of cough, mucociliary clearance, and alveolar macrophage phagocytosis is inadequate for clearance of large inocula of virulent bacteria. Under these circumstances, resident defenses are augmented by the rapid development of a pulmonary inflammatory response $[10,11]$. Additionally, specific immune responses may be generated leading to the production of specific immunoglobulins and to cell-mediated immunity.

\section{ANIMAL MODEL SYSTEMS}

The concept of an antibacterial defense system intrinsic to the pulmonary parenchyma was established utilizing an animal model at the turn of the century [12]. Animal models continue to be used extensively because the lower respiratory tract is unique with regard to phagocytic populations, levels of both immunoglobulin and complement [13-15], and the induction of immunity [15-20]. A well-characterized murine model system has been utilized to study the clearance of bacteria from the lung. Utilizing this model, the entire sequence of events involved in bacterial clearance can be studied in vivo.

Bacteria can be deposited in the lower respiratory tract by exposure to a bacterial aerosol or by an intratracheal or intrabronchial injection of fluid containing micro-organisms $[21,22]$. The foci of localized deposits of pharyngeal contents detected in human lungs and the foci of bacteria isolated from normal dog lungs were distributed in both gravity- and non-gravitydependent areas $[5,6]$, which suggests that both aspiration and aerosolization of pharyngeal secretions are responsible for the deposition of oropharyngeal bacteria into the lung. Either technique delivers a sufficiently precise and reproducible inoculum of bacteria to allow quantitation of bacterial clearance over extended time intervals and neither inoculation alters lung architecture. Following aerosol exposure, bacteria are widely dispersed throughout the lung, and the ratio of bacteria to resident phagocytes is low, whereas bolus inoculation deposits bacteria in a local- ized area of parenchyma and results in a higher bactéria-to-phagocyte ratio. At various time points after inoculation, the lungs of infected animals are removed and homogenized, and serial dilutions of the homogenates are plated on agar in order to quantify the number of viable bacteria remaining in the lung. In most experiments, several time points after inoculation are evaluated. The decline in bacteria (clearance) is the net result of three processes: mucociliary clearance, bacterial killing, and bacterial multiplication (Figure 1). Net clearance is the variable evaluated in in vivo experiments. Although bacterial clearance can be altered by changes in any of these processes, bacterial killing appears to be the rate-limiting process. In circumstances where killing is exceeded by bacterial multiplication rates, net increases in bacteria isolated from the lung will occur [23-25].

This animal model can also be used to evaluate the development of a pulmonary inflammatory response or the development of pulmonary immunity. Utilizing bronchoalveolar lavage, the number and types of cells present in the air spaces can be determined. The lavage fluid can be assayed for the presence of chemotaxins and immunoglobulins. Adequate numbers of cells are obtained for the performance of functional cellular studies or for the performance of in vitro studies of secreted cell products. A particularly attractive feature of this animal model is the ability to assess both the induction of the response (inflammation, immunity) and its expression in the lung. The model allows determination of whether the effectors (antibodies, cells) are delivered to the site of the hostbacterial interaction and whether they are functional (i.e., protective) in the lung.

\section{CLEARANCE OF OROPHARYNGEAL BACTERIA FROM THE LUNGS}

Bacteria are normally present in the oropharynx and in saliva of humans and animals. Viridans streptococci (Streptococcus salivarius and Streptococcus sangius) and aerobic gram-negative organisms (Branhamella catarrhalis and nontypable Haemophilus influenzae) are normally present in the oropharynx 


\begin{tabular}{|c|c|c|c|c|}
\hline \multicolumn{5}{|l|}{ TABLE I } \\
\hline & \multirow{2}{*}{$\begin{array}{c}\text { Deposition } \\
\text { (CFU } \times 10^{5} \text { ) } \\
\text { O Hours }\end{array}$} & \multicolumn{3}{|c|}{ Percentage of Bacteria Remaining } \\
\hline & & 1 Hour & 2 Hours & 4 Hours \\
\hline $\begin{array}{l}\text { S. sanguis } \\
\text { S. salivarius } \\
\text { B. catarmalis }\end{array}$ & $\begin{array}{l}4.7 \pm 0.3 \\
3.9 \pm 0.2 \\
4.5 \pm 0.2\end{array}$ & $\begin{array}{l}24.0 \pm 2.0 \\
49.0 \pm 3.0 \\
69.0 \pm 9.0\end{array}$ & $\begin{array}{r}8.0 \pm 1.0 \\
24.0 \pm 3.0 \\
49.0 \pm 4.0\end{array}$ & $\begin{array}{r}1.0 \pm 0.0 \\
5.0 \pm 0.0 \\
22.0 \pm 2.0\end{array}$ \\
\hline
\end{tabular}

$\mathrm{CFU}=$ colony-forming units.

* Each value represents a mean of $1 b$ to 18 animals at each interval; data are mean \pm SEM.

Data are reprinted with permission from [26]

\begin{tabular}{|c|c|c|c|}
\hline \multicolumn{4}{|c|}{$\begin{array}{l}\text { TABLE II } \\
\text { Phagocytic Cell Response* }\end{array}$} \\
\hline & \multicolumn{3}{|c|}{ Time after Aerosol } \\
\hline & 0 Hours & 2 Hours & 4 Hours \\
\hline S. sanguis & & & \\
\hline Alveolar macrophages $\times 10^{5}$ & $\begin{array}{l}9.3 \pm 1.3 \\
0.3 \pm 0.2\end{array}$ & $\begin{array}{r}18.4+1.9 \\
0.1 \pm 0.1\end{array}$ & $\begin{array}{r}196+1.4 \\
0.4 \pm 0.4\end{array}$ \\
\hline $\begin{array}{l}\text { S. salivarius } \\
\text { Alveolar macrophages } \times 10^{5} \\
\text { Granulocytes } \times 10^{4}\end{array}$ & $\begin{array}{r}10.3 \pm 0.6 \\
0.4 \pm 0.2\end{array}$ & $\begin{array}{r}13.2 \pm 0.9 \\
7.6 \pm 2.3\end{array}$ & $\begin{array}{r}12.3 \pm 1.0 \\
8.4 \pm 2.4\end{array}$ \\
\hline $\begin{array}{l}\text { B. catarmalis } \\
\text { Alveolar macrophages } \times 10^{5} \\
\text { Granulocyies } \times 10^{4}\end{array}$ & $\begin{array}{r}10.1 \pm 0.8 \\
0.1 \pm 0.1\end{array}$ & $\begin{array}{r}12.7 \pm 1.4 \\
3.4 \pm 0.8\end{array}$ & $\begin{array}{l}11.7 \pm 1.1 \\
40.9 \pm 5.5\end{array}$ \\
\hline
\end{tabular}

* Data are mean \pm SEM

Data are reprinted with permission from [26]

and in the saliva of humans and animals [7-9]. There are significant species differences in the clearance of these organisms. Ninety-five percent of aerosolized streptococci were eliminated within four hours, whereas aerosolized $B$. catarrhalis was cleared at a slower rate (Table I) [26]. Following bolus inoculation of non-typable $H$. influenzae (NTHI), a biphasic pattern was observed. During the first six hours after inoculation with NTHI, bacterial multiplication exceeded killing and the number of bacteria increased fourfold ( $395 \pm 32$ percent). During the second phase, killing exceeded multiplication and the bacteria were eradicated within 24 hours ( 2 percent bacteria remaining) [27」. These results indicate that resident defenses in mice are unable to effect eradication of oropharyngeal organisms and must be augmented for clearance to occur.

\section{PHAGOCYTIC CELL RESPONSE TO OROPHARYNGEAL BACTERIA}

Phagocytic cells are importantly involved in bacterial killing in the lung. Bronchoalveolar lavage of normal, water-aerosolized and water-bolus-injected mice resulted in similar numbers of phagocytcs (approximately 9 to $10 \times 10^{5}$ ). Alveolar macrophages appear to be the only phagocyte involved in the clearance of $S$. sangius. A doubling in the number of alveolar macrophages was noted within four hours after inoculation of $S$. sangius. Studies of changes in alveolar cell populations after challenge with $S$. salivarius, $B$. catarrhalis, and NTHI suggest that recruitment of polymorphonuclear leukocytes (PMN) is required to augment resident host defenses $[26,27]$. Challenge with $S$. salivarius resulted in a 20 -fold increase in the number of PMN at four hours, and challenge with $B$. catarrh alis resulted in a 400-fold increase in PMN (Table II). Challenge with NTHI resulted in 100-fold increase in total cells at six hours. No PMNs were present in alveolar lavage at zero hours, whereas $1.7 \times 10^{6} \mathrm{PMN}$ were isolated at six hours. At six hours, PMN constituted 63 percent of the phagocytic cells in the alveolar lavage. Thus, both alveolar macrophages and PMN are apparently important in the clearance of nost oropharyngeal bacteria.

Studies of neutropenic mice have demonstrated the importance of recruited PMN to clearance of NTHI [28]. Systemic treatment of mice with nitrogen mustard resulted in profound ncutropenia but did not alter the numbers of resident alveolar macrophages. Nitrogen mustard-treated mice were unable to recruit PMN into the lungs after NTHI challenge, and pulmonary clearance of NTHI was significantly impaired in these neutropenic animals. These data demonstrate that recruited PMN are a major component of the early defense against NTHI and are crucial for effective clearance of this oropharyngeal organism. Although similar studies have not been performed following challenges with other oropharyngeal organisms, these data suggest that PMN are important to early clearance of those organisms that result in their recruitment.

\section{MECHANISMS OF PMN RECRUITMENT}

The ability to develop an inflammatory response is a fundamental part of the pulmonary response to bacteria. The initiation of an inflammatory response involves the generation of intra-alveolar chemotaxis [29]. The specific chemotactic factors responsible for PMN recruitment following challenges with oropharyngeal organisms have been pärtially characterized using congenic C5-sufficient $\mathrm{B} 10 . \mathrm{D} 2 / \mathrm{nSn}(\mathrm{C} 5+)$ and C5-deficient B10.D2/nSn (C5-) mice. The C5- mice recruited significantly fewer PMN following challenges with NTHI than C5+ mice. The impaired influx of PMN into the lungs of $\mathrm{C5}-$ mice paralleled impaired clearance of NTHI. Thus, the C5 molecule and its fragments are important chemotaxins during the first six hours after exposure to oropharyngeal organisms [28].

Although PMN recruitment was significantly impaired during the first six hours following NTHI challenge in C5- mice, the $\mathrm{C5}-$ mice recruit near-normal numbers of PMN to the lung at 24 hours. The nature of the non-C5 chemotactic factors is speculative but probably includes alveolar macrophage-derived cytokines [30-33] and macrophage-generated products of the lipoxygenase pathway such as leukotriene $\mathrm{B}_{4}$, and 5- or 11-monohydroxyeicosatetraenoic acid $\lceil 34,35\rceil$. Alveolar macrophages have the capacity to metabolize endogenous arachidonic acid, mobilized by agonist stimulation, into substantial amounts of 5-lipoxygenase (5-LO) products. Monocytes are unable to metabolize endogenous arachidonic acid into 5-LO products. This inability to generate 5-LO products is due to a lack of coupling between arachidonic acid deacylated by phospholipase and the 5-LO enzyme. By contrast, the degree of coupling between arachidonic acid release and 5-LO metabolism increases dramatically with differentiation of monocytes to alveolar macrophages in the lung. This alteration in 5-LO metabolism of endogenous arachidonic acid, which occurs with differentiation of monocytes to al- 
veolar macrophages, is important in equipping alveolar macrophages with the ability to mount an inflammatory response in the alveolar space [36].

Alveolar macrophages also secrete numerous cytokines, which are important in neutrophil accumulation. Stimulated alveolar macrophages produce both interleukin-1 (IL-1) and tumor necrosis factor (TNF $\alpha$ ) [37,38]. Initial reports suggested these cytokines were chemotactic for neutrophils [39], but recent studies have shown that neither recombinant IL-1 nor TNF has direct chemotactic activity in vitro for neutrophils [40]. Alveolar macrophages have also been shown to generate a low molecular weight chemotactic factor after phagocytosis of microbes that preferentially attracts neutrophils [31-33]. This alveolar macrophage-derived neutrophil chemotactic factor is similar to a recently isolated and cloned monocyte $\mathrm{NCF}$ [41]. The complete nucleotide sequence of the complementary deoxyribonucleic acid of monocyte-derived NCF has recently been published. This complementary deoxyribonucleic acid encodes a 99-amino acid protein with an estimated molecular weight of 8,000 daltons for the active species. The amino acid sequence of monocyte-derived NCF shows a high degree of homology with other molecules involved in inflammation and cell growth such as beta-thromoglobulin and platelet factor 4 [42,43], suggesting this factor may be a member of a supergene family. Lipoploysaccharide, interleukin-1, and tumor necrosis factor have all been shown to increase monocytederived NCF steady state m-RNA within one hour and cause the production of biologically active NCF by monocytes [41]. Recent studies have shown that alveolar macrophages increase cellular steady-state NCF m-RNA and produce biologically active NCF in response to LPS (Strieter RM, et al, submitted for publication).

Recent studies have demonstrated that non-immune cells may participate in the generation of a pulmonary inflammatory response by the synthesis of a chemotactic factor similar to monocyte-derived NCF. Human endothelial cells produce a NCF with molecular and physiochemical characteristics consistent with monocyte-derived NCF following stimulation with tumor necrosis and interleukin-1B or lipopolysaccharide [44]. More recently, fibroblasts have been shown to have dose-dependent increases in steady-state m-RNA and to secrete a NCF similar to monocytederived NCF following exposure to $\mathrm{TNF} \alpha$, IL-1B, or II,$-1 \alpha$. In contrast, LPS and interleukin-6 failed to induce fibroblast-derived NCF [45]. Finally, IL-1 $\alpha$, IL-1B, and $\mathrm{TNF} \alpha$ have been shown to induce the expression of high levels of NCF m-RNA in a type IIlike epithelial cell line (A549). Interestingly, LPS had no effect on the induction of NCF in epithelial cells (Strieter RM, et al, submitted for publication).

The entry of bacteria or bacterial products into the lower respiratory tract initiates a complex series of events that results in the recruitment of PMN to the lung (Figure 2). The initiation of the inflammatory response involves several mechanisms including C-5derived chemotactic peptides, a cascade of macrophage-derived cytokines, and arachidonic acid metabolites and cytokines produced by non-immune cells of the alveolar-capillary membrane. It seems likely that different chemotaxins are generated in sequence such that some factors are involved in the early phases, whereas others are important at later time points.

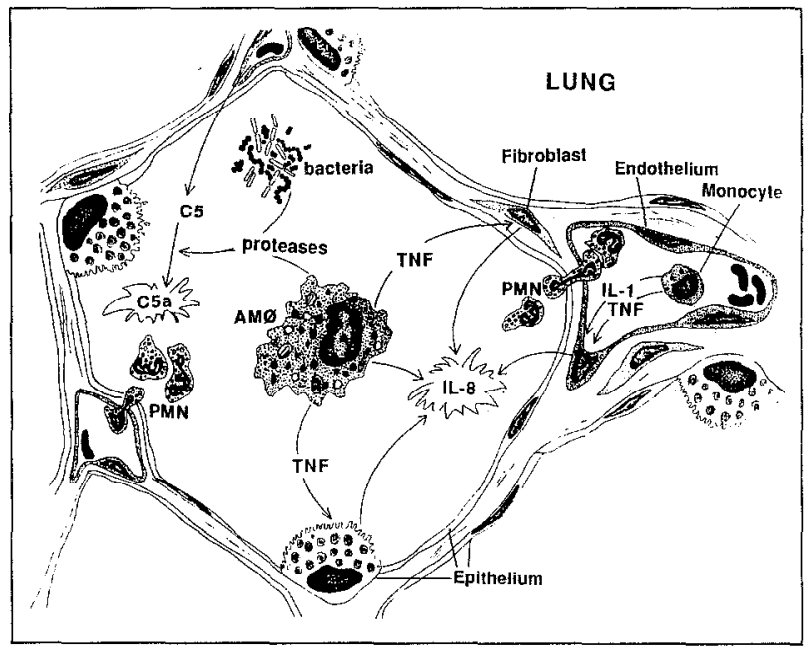

Figure 2. Mechanism of granulocyte recruitment to the lung. The entry of bacteria or bacterial products into the lower respiratory tract initiates a complex series of events that results in the recruitment of PMN to the lung.

\begin{tabular}{|cc|}
\hline $\begin{array}{l}\text { TABLE III } \\
\text { Effect of Systemic Immunization with an Outer Membrane } \\
\text { Protein/LPS Complex on Pulmonary Clearance of NTHI }\end{array}$ \\
\hline Immune Status & $\begin{array}{c}\text { Percent Bacteria Remaining } \\
\text { at } 6 \text { Hours Post Challenge }\end{array}$ \\
\hline Control & $358 \pm 30$ \\
Immune & $16 \pm 1$ \\
\hline
\end{tabular}

\begin{tabular}{|cc|}
\hline TABLE IV \\
Effect of Intravenous Administration of a LPS-Specific \\
Monoclonal Antibody on Pulmonary Clearance of NTHI \\
\hline Immunization Agent & $\begin{array}{c}\text { Percent Bacteria Remaining } \\
\text { at } 6 \text { Hours Post Challenge }\end{array}$ \\
\hline Phosphate-buffered saline & $396 \pm 37$ \\
Monoclonal antibody 6A10 & $43 \pm 3$ \\
\hline
\end{tabular}

C-5-derived peptides are important in the first six hours following bacterial entry, whereas macrophage and non-immune cell-derived NCFs are likely important at later time points. Although a variety of cellular components in the lung can express NCF, this expression is stimulus-specific. Both endothelial cells and alveolar macrophages can express NCF m-RNA and functionally active NCF in response to primary bacterial products such as LPS. Alternatively, fibroblasts and type II epithelial cells only produce NCF in response to alveolar macrophage- and monocyte-induced cytokines, IL-1 and TNF. The coordinated participation of mononuclear phagocytes, endothelial cells, fibroblasts, and epithelial cells is likely required for the generation of the chemotactic gradient required for PMN recruitment.

\section{SPECIFIC HUMORAL IMMUNITY}

Normal bronchoalveolar washings contain immunoglobulin G (IgG) and IgA [46], but it is uncertain what role immunoglobulin plays in resident defenses within the alveolus. Normal mice have been shown to have no 
specific serum antibodies against normal oropharyngeal flora $[26,47]$. Although the role of immunoglobulin in resident pulmonary antibacterial defenses is uncertain, it is clear that immunization can enhance early clearance of bacteria from the lower respiratory tract. Systemic immunization with NTHI resulted in NTHI-specific antibody in both serum and bronchoalveolar lavage. The concentration of NTHI-specific antibody in serum of immunized animals was 1,000fold higher than in serum of controls, whereas the concentration of NTHI-specific antibody in bronchoalveolar lavage was at least 200-fold greater than in bronchoalveolar lavage obtained from control animals. Western blot analysis revealed that the specificities of antibodies in bronchoalveolar lavage were identical with those of antibodies in the serum demonstrating that serum IgG can enter the alveolar spaces of the uninflamed lung, probably by transudation. Thus, direct airway immunization is not required to generate protective, specific antibody in the air spaces of the lung [47].

An acellular NTHI antigen preparation has also been shown to generate protective antibodies in the air spaces. Mice immunized with an outer membrane protein-lipo-oligosaccharide complex produced antibodies directed against both immunogens and the presence of these antibodies was correlated with a marked enhancement of pulmonary clearance of NTHI (Table III). Although these data do not allow a determination of the role of cellular versus humoral immunity, passive intravenous immunization of mice with a LPS-specific monoclonal antibody resulted in markedly enhanced lower respiratory tract clearance of NTHI (Table IV) [48]. Taken together, these data suggest that immunoprophylaxis or immunomodulation of NTHI disease in the lungs is feasible.

\section{REFERENCES}

1. Pecora DV, Yegian D: Bacteriology of the lower respiratory tract in health and chronic diseases. N Engl J Med 1958; 258: 71-74.

2. Lees AW, McNaught W: Bacteriology of lower-respiratory-tract secretions, sputum and upper-respiratory-tract secretions, in "normals" and chronic bronchitis. Lancet 1959: II: $1112-1115$

3. Laurenzi GA, Potter RT, Kass [II: Bacteriologic flora of the lower respiratory tract. N Engl J Med 1961; 265: 1273-1278.

4. Lindsey J0, Pierce AK: An examination of the microbiologic flora of normal lung of the dog. Am Rev Respir Dis 1978; 117: 501-505.

5. Mays B, Thomas G, Leonard J, Southern P, Pierce AK, Sanford JP: Gram-negative bacillary necrotizing pneumonia: a bacteriologic and histopathologic correlation. J Infect Dis 1969: 120: 687-697.

6. Huxley EJ, Viroslav J, Gray WR, Pierce AK: Pharyngeal aspiration in normal adults and patients with depressed consciousness. Am J Med 1978; 64: 564-568.

7. Gibbons RJ, Van Houte J: Oral bacterial ecology. In: Shaw JH, Sweeney E, Cappuccino C, Miller S, eds. Textbook of oral biology. Philadelphia: W.B. Saunders, 1978; 684-/05.

8. Burnett G, Schup H, Schuster G (eds): Microbial flora of the oral cavity. In: Oral microbiology and infectious diseases. Baltimore: Williams \& Wilkins, 1976; 219-258.

9. Distribution and development of the microbiota of man. In: Roseburg T, ed. Microorganisms indigenous to man. New York: McGraw-Hill, 1962; 310-350.

10. Pierce AK, Reynolds RC, Harris GD: Leukocytic response to inhaled bacteria. Am Rev Respir Dis 1977; 116: 679-684.

11. Toews GB, Gross GN, Pierce AK: The relationship of inoculum size to lung bacterial clearance and phagocytic cell response in mice. Am Rev Respir Dis 1979; 120: 559-566. 12. Briscoe JC: An experimental investigation of the phagocytic action of the alveolar cells of the lung. J Pathol Bacteriol 1908; 12: 66-100.

13. Green GM, Jakab GJ, Low RB, Davis GS: Defense mechanisms of the respiratory membrane. Am Rev Respir Dis 1977: 115: 479-514.

14. Newhouse $M$, Sanchis J, Bienenstock J: Lung defense mechanisms. N Engl J Med 1976; 295: 990-998, 1045-1052.

15. Kaltreider BH: Expression of immune mechanisms in the lung. Am Rev Respir Dis 1976; 113: 347-349.

16. Toews GB, Vial WC, Durn MM, et al: The accessory cell function of human alveolar macrophages in specific T cell proliferation. J Immunol 1984; 132: 181-186. 17. Lyons CR, Ball EJ, Toews GB, Weissler JC, Stastny P, Lipscomb MF: Inability of human alveolar macrophages to stimulate resting $T$ cells correlates with decreased antigen specific T cell-macrophage binding. J Immunol 1986; 137: 1173-1180.

18. Nicod LP, Lipscomb MF, Toews GB, Weissler JC: Separation of potent and poorly functional human lung accessory cells hased on autoflunrescence. J Leukacyte Biol 1989 45: $458-465$

19. Kaltreider BH, Caldweli SL, Byrd PK: The capacity of normal aiveolar macrophages to function as antigen presenting cells for the initiation of primary antibody-forming cell responses to sheep erythrocytes in vitro. Am Rev Respir Dis 1986; 133: 1097-1104. 20. Klinkert WEF, LaBadie JH, Bower WE: Accessory and stimulating properties of dendritic cells and macrophages isolated from various rat tissues. J Exp Med 1982; 156 $1-19$.

21. Gross GN, Rehm SR, Pierce AK: The effect of complement depletion on lung clearance of bacteria. J Clin Invest 1978; 62: 373-378.

22. Onofrio JM, Toews GB, Lipscomb MF, Pierce AK: Granulocyte-alveolar macrophage interaction in the pulmonary clearance of Staphylococcus aureus. Am Rev Respir Dis 1983; 127: 335-341

23. Jay SI, Johanson WG Jr, Pierce AK, Rejsch JS: Determinants of lung bacterial clearance in normal mice. J Clin Invest 1976; 57: 811-817.

24. Rehm SR, Gross GN, Pierce AK: Early bacterial clearance from murine lungs: speciesdependent phagocyte response. J Clin Invest 1980; 66: 194-199.

25. Toews GB, Vial WC, Hansen EJ: Role of $C 5$ and recruited neutrophils in early clearance of nontypable Haemophilus infiluenzae from murine lungs. Infect Immun 1985; 50: 207 212.

26. Onofrio JM, Shuikin AN, Heidbrink PJ, loews EBB, Pierce AK: Pulmonary clearance and phagocytic cell response to normal pharyngeal flora. Am Rev Respir Dis 1981; 123: 222 225.

27. Toews GB, Viroslav $S$, Hart DA, Hansen EJ: Pulmonary clearance of encapsulated and nonencapsulated Haemophilus infiuenzae strains. Infect Immun 1984; 45: 437-442. 28. Toews GB, Vial WC, Hansen EJ: Role of $C 5$ and recruited neutrophils in early clearance of nontypable Haemophilus infiuenzae from murine lungs. Infect Immun 1985; 50; 207 212.

29. Vial WC, Toews GB, Pierce AK: Early pulmonały granulocyte recruitment in response to Streptococcus pneumoniae. Am Rev Respir Dis 1984; 129: 87-91.

30. Kazmierowski JA, Gallin JI, Reynolds HY: Mechanism for the inflammatory response in primate lungs: demonstration and partial characterization of an alveolar macrophagederived chemotactic factor with preferential activity for polymorphonuclear leukocytes. J Clin Invest 1977; 59: 273-281.

31. Hunninghake GW Gallin Jl, Fauci AS: Immunologic reactivity of the lung. The in vitro generation of a neutrophil chemotactic factor by alveolar macrophages. Am Rev Respir Dis 1978; 117: 15-23.

32. Hunninghake GW, Gadek JE Fales HM, Crystal RG: Human alveolar macrophagederived chemotactic factor for neutrophils, stimuli and partial characterization. J Clin Invest 1980; 66: 473.483

33. Merrill WW, Naegel GP, Matthay RA, Reynolds HY: Alveolar macrophage-derived chemotactic factor, kinetics of in vitro production and partial characterization. J Clin Invest 1980; 65: 268-276.

34. Ford-Hutchinson AW, Bray MA, Doig MV, Shipley ME, Smith MJ: Leukotriene B, a potent chemokinetic and aggregating substance released from polymorphonuclear leukocytes. Nature 1980; 286: 264-265.

35. Valone FH, Franklin M, Sun FF, Goetzl EJ: Alveolar macrophage lipoxygenase products of arachidonic acid: isolation and recognition as the predominant constituents of the neutrophil chemotactic activity elaborated by alveolar macrophages. Cell Immunol 1980; 54: $390-401$

36. Balter MS, Toews GB, Peters-Golden M: Different patterns of arachidonate metabolism in autologous human blood monocytes and alveolar macrophages. J Immunol 1989; 142: $602-608$.

37. Bachwich PR, Chensue SW, Larrick J, Kunkel SL: Tumor necrosis factor stimulates interleukin- $I$ and prostaglandin $E_{2}$ production in resting macrophages. Biochem Biophys Res Commun 1986; 136: 94-101

38. Bachwich PR, Lynch JP, Larrick J, Spengler M, Kunkel SL: Tumor necrosis factor production by human sarcoid alveolar macrophages. Am J Pathol 1986; 125: 421-425. 39. Sauder DN, Mounessa NL, Katy SI, Dinerallo CA, Gallin JL: Chemotactic cytokines: the role of leukocytic pyrogen and epiderma cell lymphocyte-activating factor for neutrophil chemotaxis. J immuno! 1984; 132: 828-832.

40. Yoshimura T, Matsushima K, Oppenheim JJ, Leonard EJ: Neutrophil chemotactic factor produced by LPS-stimulated human blood mononuclear leukocytes: partial characterzation and separation from interfeukir-1. J Immunol 1987; 139: 788-793.

41. Matsushima K, Morishita K, Yoshimura T, et al: Molecular cloning of a human monocyte-derived neutrophil chemotactic factor (MDNCF) and the induction of MDNCF $\mathrm{m}$-RNA by interleukin-1 and tumor necrosis factor. J Exp Med 1988; 167: 1883-1893.

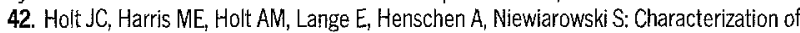
human platelet basic protein, a precursor form of low-affinity platelet factor 4 and betathromboglobulin. Biochemistry 1986; 25: 1988-1996.

43. Deuel TF, Keim PS, Farmer M, Heinrikson RL: Amino acid sequence of human platelet factor 4. Proc Natl Acad Sci USA 1977; 74(6): 2256-2258.

44. Strieter RM, Kunkel SL, Showell JH, et al: Endothelial cell gene expression of a neutrophil chemotactic factor by TNF $\alpha$, LPS, and IL-1 $\beta$. Science 1989; 243: 1467-1469.

45. Strieter RM, Phan SH, Showell HJ, et al: Monokine-induced neutrophil chemotactic factor gene expression in human fibrobjasts. J Biol Chem 1989; 264: 10621-10626. 46. Reynolds HY, Newball HH: Analysis of proteins and respiratory cells obtained from human lungs by bronchia! lavage. J Lab Clin Med 1974; 84: 559-573.

47. Hansen EJ, Hart DA. McGchce JL, Toews GB: Immune enhancement of pulmonary clearance of nontypable haemophilus influenzae. Infect Immun 1988; 56: 182-190. 48. McGehee $J L$, Radolf JD, Toews GB, Hansen EJ: Effect of primary immunization on pulmonary clearance of nontypable Haemophilus influenzae. Am J Respir Cell Mol Biol 1989; 1: 201-210.

49. Johanson WG: Lung defense mechanisms. In: Basics of respiratory disease. New York: American Lung Association, 1977 